\title{
Operational performance of an agricultural tractor under different tire inflation pressures in the subsoiling operation
}

\author{
Arthur Gabriel Caldas Lopes ${ }^{1}$, Tiago Pereira da Silva Correia ${ }^{1}$, Gabriel Pastor de Barros \\ Lima $^{1}$, Isabela Dias de Souza ${ }^{1}$, Wesley Matheus Cordeiro Fulgêncio Taveira ${ }^{1}$, Gabriela Greice \\ Pereira $^{1}$
}

\author{
${ }^{1}$ Universidade de Brasília, Campus Darcy Ribeiro, Brasília, Distrito Federal, Brasil. E-mail: arthur.grb10@gmail.com, \\ tiagocorreia@unb.br, gabrielbarroslima77@gmail.com, isabela99dias99@gmail.com, wmctaveira@gmail.com, \\ gabi_greice@hotmail.com
}

Received: 27/04/2020; Accepted: 31/08/2020.

\begin{abstract}
For the agricultural tractor's best performance, it must be correctly adapted to the job. Among other factors, the adequacy of tire inflation pressure is one of the most important and may influence the operation's efficiency and productivity. This study aimed to evaluate an agricultural tractor's operational performance with different tire inflation pressures in the subsoiling operation. The study was carried out in an experimental area of the Agricultural Machinery and Mechanization Laboratory of the experimental farm “Água Limpa," belonging to the University of Brasília. The experimental design used was in randomized blocks with the following values, $206.8 \mathrm{kPa}(30 \mathrm{psi})$, $137.9 \mathrm{kPa}(20 \mathrm{psi})$, and $68.9 \mathrm{kPa}$ (10 psi), of inflation pressure for agricultural tractor tires. The mechanized set used was a tractor model TM7020 2WD MFWD pulling a subsoiler with five shanks, SPCR model, in a Latossolo Vermelho-Amarelo. The higher inflation pressure resulted in greater slippage, advance, hourly fuel consumption, and lower speed and operational field capacity.
\end{abstract}

Keywords: calibration, fuel consumption, slippage, tillage, operational performance.

\section{Desempenho operacional de um trator agrícola sob diferentes pressões de inflação dos pneus na operação de subsolagem}

\section{RESUMO}

Para o melhor desempenho do trator agrícola, é preciso que este esteja corretamente adequado ao trabalho. Dentre outros fatores, a adequação da pressão de inflação dos pneus é um dos mais importantes, podendo influenciar na eficiência e produtividade da operação. O objetivo do trabalho foi avaliar o desempenho operacional de um trator agrícola com diferentes pressões de inflação dos pneus na operação de subsolagem. O trabalho foi realizado em área experimental do Laboratório de máquinas e mecanização agrícola da Fazenda Experimental Água Limpa, pertencente à Universidade de Brasília. O delineamento experimental utilizado foi em blocos casualizados com os seguintes tratamentos: 206,8 kPa (30 psi), 137,9 kPa (20 psi) e 68,9 kPa (10 psi) de pressão de inflação dos pneus do trator agrícola. O conjunto mecanizado utilizado foi um trator modelo TM7020 4 x 2 TDA tracionando um subsolador com cinco hastes modelo SPCR, em Latossolo Vermelho-amarelo. A maior pressão de inflação resultou em maior patinagem, avanço e consumo horário de combustível, e menor velocidade e capacidade de campo operacional.

Palavras-chave: calibragem, consumo de combustível, patinagem, preparo do solo, rendimento operacional. 


\section{Introduction}

The internal tire pressure directly affects the operating performance with an agricultural tractor. According to Misiewicz et al. (2015), adequate tire pressure provides dynamic balance to the tractor, higher tractive efficiency, and better contact of the tread with the ground. According to Spagnolo et al. (2012) and Jadoski et al. (2016), the combination of tire calibration pressure factors such as type of tires and ballast of the tractor can positively or negatively influence its slippage and kinematic advance, operational performance, tire life, and fuel consumption.

According to Biris et al. (2011), tires with low pressure suffer an exaggerated deflection in the carcass's central part, increasing the rolling resistance. High inflation pressures cause less tire adherence to the ground and accelerate wear, which occurs irregularly, especially in the rear tires.

As Mion et al. (2016) reported, the effects of incorrect inflation of tractor tires can be observed in the soil's physical aspects. The authors found in a study performed with inflation pressures in the rear tires of a farm tractor of $96.5,124,151$, and $179 \mathrm{kPa}$, as well as a condition of loamy sand soil with $10.35 \%$ humidity, that the lowest pressure caused the lowest tension in the soil, demonstrating the relevance of reducing the pressure to decrease soil compaction to depths of $0.30 \mathrm{~m}$. The highest pressures caused the largest deformations in the soil caused by reducing the tire-soil contact area. In the study, the authors cite that it is necessary to seek solutions to reduce working pressures to cause less superficial soil compaction due to vertical and horizontal tensions.

Feitosa et al. (2015) cite that not only the tire inflation pressure can be decisive to influence the physical aspects of the soil, but the constructive model, whether diagonal or radial, as well as the tire dimensions. The influence of internal pressures on the diagonal tires of the front and rear axles of an agricultural tractor of 83 and $86 \mathrm{kPa}, 96$ and $110 \mathrm{kPa}$, and 110 and $124 \mathrm{kPa}$, respectively, were evaluated, leading the authors to conclude that in Argissolo Vermelho-Amarelo, the application of pressures of 110 and $124 \mathrm{kPa}$ on the front and rear tires caused the highest reduction in total soil porosity.

On the constant concern with the rational use of energy resources and the reduction of mechanized costs, Montanha et al. (2011) address that the fuel consumption demanded by the tractor-implement set can be optimized based on the suitability of the tires to work, since they have the function of displacing, balancing, directing and damping the set; for these reasons, the pressure used becomes an aspect of fundamental regulation, aiming at the operation performance and economy.
This study aimed to evaluate an agricultural tractor's operational performance with different tire inflation pressures in the subsoiling operation.

\section{Material and Methods}

The work was carried out at the Agricultural Machinery and Mechanization Laboratory of the experimental farm "Água Limpa" (Lamagri/FAL), belonging to the University of Brasília.

The area used is located on the geographical coordinates $15^{\circ} 57^{\prime} 00^{\prime \prime} \mathrm{S}$ and $47^{\circ} 55^{\prime} 41^{\prime}$ ' W, and an average altitude of $1109 \mathrm{~m}$. The soil was classified by Papa et al. (2011) as Latossolo Vermelho-Amarelo (LVA) with a clay texture. The average water content in the soil during the experiment was $23 \%$, obtained from six random samples of soil between the $0.0-0.3 \mathrm{~m}$ layers of the experimental area, submitted to the standard oven method (EMBRAPA, 2011). The average soil density was $0.096 ; 0.074$ and $0.046 \mathrm{~g} \mathrm{~cm}-3$ at depths of $0.0-0.1 ; 0.1-0.2$, and $0.2-0.3$, respectively, obtained from random samples by the volumetric ring method (EMBRAPA, 2011).

The average temperature of the day during the experiment was $22.7{ }^{\circ} \mathrm{C}$. The area's history is with corn cultivation in a no-tillage system, with the soil covered by spontaneous vegetation and $8032.8 \mathrm{~kg} \mathrm{ha}^{-1}$ of residual straw from the grain harvest.

The experimental design used was in randomized blocks with four repetitions per treatment, with the values $206.8 \mathrm{kPa}$ (30 psi), $137.9 \mathrm{kPa}(20 \mathrm{psi})$, and $68.9 \mathrm{kPa}(10$ psi) of inflation pressure of the four tires of the agricultural tractor. The pressure $137.9 \mathrm{kPa}$ (20 psi) was adopted according to the tire manufacturer's technical recommendation, and the lower and higher pressures were established to simulate inadequate pressure and extreme use conditions in the field. The experimental plots were $80 \mathrm{~m}$ long and $5 \mathrm{~m}$ wide.

The mechanized set consisted of a Piccin subsoiler, model SPCR, equipped with five shanks spaced $0.4 \mathrm{~m}$ from each other, with tips $0.08 \mathrm{~m}$ wide, without wings, straw cutting discs of $0.46 \mathrm{~m}$, a cutting roller, and 1550 $\mathrm{kg}$ in weight. The subsoiler worked with the shanks at a depth of $0.35 \mathrm{~m}$, driven by the drawbar of a New Holland tractor, model TM7020 2WD MFWD, with $109.58 \mathrm{~kW}$ (149hp) of engine power, the total weight of $7125 \mathrm{~kg}$, $2494 \mathrm{~kg}$ on the front axle and $4631 \mathrm{~kg}$ on the rear axle.

On the tractor's front axle, two diagonal tires of the Pirelli brand model TM95, type R1 were used, with measures 18.4-26, consisting of 12 tarps and claws 0.043 $\mathrm{m}$ high. Two Goodyear diagonal tires, model Dyna Torque II, type R1, with measures 20.8-38, 14 tarps, and $0.052 \mathrm{~m}$ high claws were employed on the rear axle. The four tires used $75 \%$ of the volume with liquid ballast. 
The slippage index $(\mathrm{P})$ of the rear wheels was determined according to the methodology described by Mialhe (1996), obtained by Equation 1.

$$
\mathrm{P}(\%)=\frac{\mathrm{SC}-\mathrm{CC}}{\mathrm{SC}} \times 100
$$

Where:

P: Slippage index $(\%)$

$\mathrm{CC}$ : Number of turns of the rear wheels with tractive force on the drawbar (implement lowered).

SC: Number of turns of the rear wheels without traction force on the drawbar (implement lifted).

The kinematic advance index (A) of the front wheels was determined by Equation 2, according to the methodology described by Gameiro and Lanças (1996).

$$
A(\%)=\frac{C T-S T}{S T} \times 100
$$

Where:

A: Kinematic advance index (\%)

CT: Number of turns of the front wheelset with the MFWD on

ST: Number of turns of the front wheelset with the MFWD off

Hourly fuel consumption (Hfc) was determined using the standard test tube methodology described by Sichocki et al. (2013). Two $1000 \mathrm{ml}$ beakers, graduated in a $10 \mathrm{ml}$ scale, were installed in the tractor's fuel supply system, one supplying diesel for the injection pump supply and the other receiving the nozzle return. At the entrance of each plot, the feeding beaker was filled with known volume, and at the end, subtracting the volumes of each beaker, consumption data were obtained and submitted to Equation 3 to determine the Hfc. The time required to travel within each plot was measured with a digital timer.

$$
H f c=\frac{V i-V r}{t} \times 3,6
$$

Where

Hfc: Hourly fuel consumption $\left(\mathrm{L} \mathrm{h}^{-1}\right)$

Vi: Volume of fuel consumed in the inlet beaker (L)

Vr: Volume of fuel consumed in the return beaker $(\mathrm{L})$

$\mathrm{t}$ : Time necessary to travel the plot (s)

3,6: Transformation constant

According to the methodology described by Mialhe (1974), the operational field capacity was determined, being used in equation 4 .

$$
\text { Ofc }=\frac{\text { W.s }}{10} x \mathrm{Ef}
$$

Where

Ofc: Operational field capacity (ha $\left.\mathrm{h}^{-1}\right)$

$\mathrm{W}$ : Actual working width of the machine (m)

$\mathrm{s}$ : Working speed $\left(\mathrm{km} \mathrm{h}^{-1}\right)$

Ef: Field efficiency expressed in decimal (75\%)

The data obtained were subjected to variance analysis and the averages compared by Tukey's test at 5\% significance, with the statistical software $\mathrm{R}$, version 1.1.463.

\section{Results and Discussion}

The results from the variance analysis for the investigated variables are shown in Table 1 and demonstrate significance for all variables. Slippage $(\mathrm{P})$, kinematic advance (A), operating speed (V), and operational field capacity (Ofc) have a significance level of $1 \%$ probability of error, and hourly fuel consumption (Hfc) exhibits a significance of 5\% probability of error.

The slippage $(\mathrm{P})$ and advance $(\mathrm{A})$ results are shown in Figure 1 and indicate that the wheels' inflation pressures differed by the variable.

The lowest inflation pressure showed a slippage of $10.58 \%$, an index 21.5 , and $34.1 \%$ lower than those seen in intermediate and higher pressures. As suggested by Godinho Júnior et al. (2017), slippage at the highest inflation pressure can be considered outside the acceptable efficiency limit for firm soils, considered ideal from 10 to $15 \%$ by the authors.

The result can be understood, according to Santos et al. (2016). They found a linear increase of $0.053 \%$ in slippage by increasing a pressure unit $(\mathrm{kPa})$ in the tires when studied an agricultural tractor with different tire inflation pressures in tillage operation. That slippage should be due to the occurrence of a smaller area of contact between the tire's tread and the ground, causing less grip and traction, thus increasing slippage.

The result of less slippage with lower inflation pressure corroborates that verified by Janulevicius et al. (2019). They found that slippage was reduced by $11 \%$ when the tire pressure was reduced from 240 to $80 \mathrm{kPa}$ when working with different inflation pressures on an agricultural tractor's tires.

It is observed that when the inflation pressure of the front tires increases, the rate of kinematic advance increases. At the lowest pressure $(68.9 \mathrm{kPa})$, the advance was $1.49 \%, 49.1$, and $68.8 \%$ less than at 137.9 and 206.8 $\mathrm{kPa}$, respectively. The result is possibly due to the association between an increase in the rolling radius and a smaller area of wheel-to-ground contact when the pressure is higher and to the requirement for traction force on the drawbar by the subsoiler, described by Feitosa et al. (2015).

The slippage result differs from that obtained by Feitosa et al. (2015) when comparing three inflation pressures in an agricultural tractor's rear wheels, 96, 110, and $124 \mathrm{kPa}$. The author identified that these values did not significantly affect the wheelset slippage, obtaining an average of $1 \%$. The low value obtained and the divergence with the current work are due to the tractor used by the authors was not subjected to efforts on the drawbar.

The kinematic advance is substantially increased by the increase in the wheelsets' inflation pressure, being higher $(4.78 \%)$ at $206.8 \mathrm{kPa}$. The result is in line with Leite et al. (2017), who detected an increase of $0.026 \%$ 
in the slip index for each unit of pressure added to the tires at the same speed, justified by the increase in the rolling radius of the tires.

According to Janulevicius et al. (2017), with the reduction of the wheelsets' inflation pressure, there is a reduction of its rolling radius; thus, the front wheels acquire greater rotation than the rear wheels, increasing the kinematic advance. However, the result obtained at the highest pressure is between 1 and $5 \%$, limits described by Feitosa et al. (2015) as being suitable for the agricultural tractor's good performance, if the slippage does not exceed $20 \%$.

The wheels' inflation pressures have relevance to the variables shown in Figure 2 since they reflect the influence of the results of Figure 1 on the wheel rolling, traction efficiency, and energy efficiency of the tractor. The results reveal that excessive pressure induces greater slippage (Figure 1) due to the wheels' larger rolling radius, the smaller contact area, and the wheel-to-ground adhesion. Thus, energy efficiency is hindered by the increase in fuel consumption for improper rotation of wheelsets and the loss of travel speed. If impaired the speed of an implement, the operational field capacity will be reduced.

Table 1. Analysis of variance for the studied variables according to the pressure of the tire inflation of the agricultural tractor.

\begin{tabular}{cccccc}
\hline \multirow{2}{*}{ Variable } & \multicolumn{5}{c}{ Anova } \\
\cline { 2 - 5 } & SI & A & Hfc & OS & Ofc \\
\hline F-test & 100.65 & $591.26^{*}$ & 7.72 & $66.84^{*}$ & $74.47^{*}$ \\
CV (\%) & 4.08 & 4.42 & 4.98 & 3.20 & 3.05 \\
MSD & 1.07 & 0.26 & 2.74 & 0.30 & 0.05 \\
SE & 0.273 & 0.067 & 0.69 & 0.078 & 0.013 \\
SD & 0.564 & 0.135 & 1.38 & 0.156 & 0.026 \\
\hline
\end{tabular}

P: slippage; A: advance; Hfc: hourly fuel consumption; V: operational speed; Ofc: operational field capacity. ${ }^{*}$ Significant at the $5 \%$ level of error probability. ** Significant at the level of $1 \%$ probability of error. $\mathrm{CV}$ : coefficient of variation; MSD: minimum significant difference; SE: standard error of the average; SD: standard deviation.

Figure 1. Slippage and kinematic advance (\%) at different tire inflation pressures.

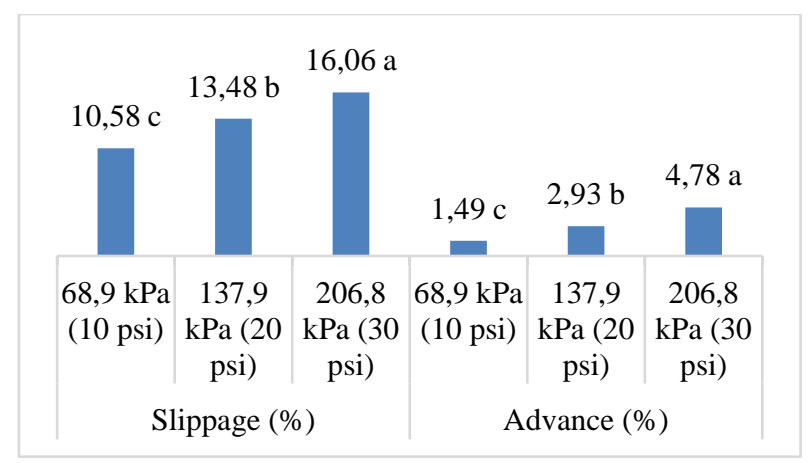

Means followed by the same lowercase letter do not differ from each other by the Tukey test at the 5\% level of significance.
Figure 2. Hourly fuel consumption (Hfc), operational speed $(\mathrm{V})$, and operational field capacity (Ofc).

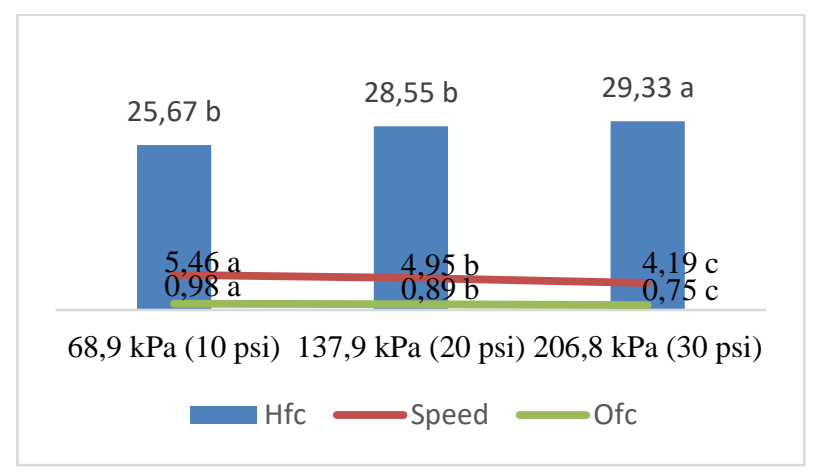

Means followed by the same lowercase letter do not differ from each other by the Tukey test at the 5\% level of significance.

The lowest hourly fuel consumption (Hfc), 25.67 $\mathrm{L} \mathrm{h}^{-1}$, was obtained by the $68.9 \mathrm{kPa}$ inflation pressure of the wheelsets, whose slippage and the kinematic advance was lower (Figure 1). Due to the lower slippage and advance, the Hfc of the lowest pressure was 10.1 and $12.4 \%$ lower than the values corresponding to $68.9 \mathrm{kPa}$ and $137.9 \mathrm{kPa}$, respectively. Between 137.9 and 206.8 $\mathrm{kPa}$, Hfc did not differ significantly, although slippage and advance did diverge.

The result corroborates that found by Montanha et al. (2011), who studied two tire inflation pressures, 124 and $242 \mathrm{kPa}$, and found that, at the lowest pressure, there was a $3 \%$ reduction in hourly fuel consumption. However, it differs from that found by Mamkagh (2018), when verifying that the fuel economy increased from $7.3 \%$ to $11.4 \%$ by increasing the tire inflation pressure from 110 to $159 \mathrm{kPa}$.

The operating speed (V) was reduced by 15.3 and $23.3 \%$ from the highest pressure $(206.8 \mathrm{kPa})$ to 137.9 and $68.9 \mathrm{kPa}$, respectively. The lower speed of the highest pressure, $4.19 \mathrm{~km} \mathrm{~h}-1$, occurred due to the greater slippage and the wheelsets' kinematic advance, which delayed the fluent movement of the mechanized set. In this context, Rosca et al. (2014) describe that the tires' pressure is directly related to the operational speed that the tractor-implement set can develop. This is due to the tire's contact and adherence to the soil surface, which may be greater or lesser and may vary according to the inflation pressure used. However, the discussion is different from that described by Amorim et al. (2019) when they tested a tractor-seeder set with two tire inflation pressures and did not find an operational speed variation. The result is possibly the consequence of the lower traction force required by the seed drill compared to the subsoiler.

Directly dependent on operational speed, the operational field capacity (Ofc) was lower, $0.75 \mathrm{ha} \mathrm{h}^{-1}$, at the highest tire inflation pressure, whose speed was lower. The context discussed for understanding the lower 
speed results is synchronous to the Ofc obtained and agrees with Taghavifar and Mardani (2014). They describe the loss of operational speed due to greater slippage of the wheels when the power provided by the tractor is reduced from 20 to $55 \%$. Similarly, Simões et al. (2011) detected the loss of subsoiling Ofc when, in a gentle slope, the tractor suffers greater slippage due to the greater traction effort, with reduced travel speed and increased fuel consumption.

Damanauskas et al. (2015) state that adding ballast (load) to the tractor and reducing the tire inflation pressure are possible measures to be adopted to decrease the wheelset slip index, increase speed, and Ofc. However, the authors mention that these actions can increase fuel consumption, as verified in the results presented in Figure 2. Evaluating four inflation pressures of the wheels and different ballast masses of the tractor, Damanauskas et al. (2015) found that the condition of higher pressure $(240 \mathrm{kPa})$ without ballast provided greater slippage $(13.5 \%)$ and lower Ofc $\left(1.36 \mathrm{ha} \mathrm{h}^{-1}\right)$ concerning the condition of lower pressure $(100 \mathrm{kPa})$ with greater ballast mass, with values of $6.6 \%$ for slippage and $1.46 \mathrm{ha} \mathrm{h}^{-1}$ for Ofc.

\section{Conclusions}

Given the conditions of the current work, it can be understood that the higher inflation pressure of the tractor tires provokes less subsoiling operational productivity, higher hourly fuel consumption, slippage, and the kinematic advance of the tractor wheels.

\section{Bibliographic References}

Amorim, M.Q., Nicolau, F.E.A., Mendonça, C.A., Santos, P.R.A., Chioderoli, C.A., 2019. Desempenho operacional do conjunto trator semeadora adubadora de fluxo contínuo em função da pressão de inflação dos rodados e velocidade de deslocamento. Energia na Agricultura, 34(2), 152-161. DOI: 10.17224/EnergAgric.2019v34n2p152-161.

Biris, S.S., Ungureanu, N., Maican, E., Murad, E., Vladut, V., 2011. FEM model to study the influence of tire pressure on agricultural tractor wheel deformations. Engineering for Rural Development, 10, 223-228.

Damanauskas, V., Janulevičius, A., Pupinis, G., 2015. Influence of extra weight and tire pressure on fuel consumption at normal tractor slippage. Journal of Agricultural Science, 7(2), 55-67. DOI: 10.5539/jas.v7n2p55.

EMBRAPA. Empresa Brasileira de Pesquisa Agropecuária, 2011. Manual de métodos de análise de solo, segunda ed. Rio de Janeiro, Embrapa Solos, 230 p.

Feitosa, J.R., Fernandes, H.C., Teixeira, M.M., Cecon, P.R., 2015. Influência da pressão interna dos pneus e da velocidade de deslocamento nos parâmetros operacionais de um trator agrícola e nas propriedades físicas do solo. Engenharia
Agrícola, 35(1), 117-127. DOI: 10.1590/1809-4430Eng.Agric.v35n1p117-127/2015.

Gamero, C.A., Lanças, K.P., 1996. Ensaio e certificação das máquinas de mobilização periódica do solo, in: Mialhe, L.G. Máquinas agrícolas: ensaios e certificação. Piracicaba, Fundação de estudos agrários Luiz de Queiroz, 463-514.

Godinho Júnior, J.D., Litordi, V.R.V., Vieira, L.C., Ruas, R.A.A., 2017. Insuflagem versus eficiência. Cultivar Máquinas, 15(172), 34-36.

Jadoski, G.S., Pinheiro, T.D., Santos Júnior, P.S., Rodrigues, F.R.M., 2016. Influence of the tyre characteristics on the tractor performance. Applied Research \& Agrotechnology, 9(2), 115120. DOI: 10.5935/PAeT.V9.N2.13.

Janulevicius, A., Juostas, A., Pupinis, G., 2019. Estimation of tractor wheel slippage with different tire pressures for $4 \mathrm{wd}$ and 2 wd driving systems. Engineering for Rural Development, 8893. DOI: 10.22616/ERDev2019.18.N096.

Janulevicius, A., Pupinis, G., Lukštas, J., Damanauskas, V., Kurkauskas, V., 2017. Dependencies of the lead of front driving wheels on different tire deformations for a MFWD tractor. $\begin{array}{llll}\text { Transport, } & 32(1), & 23-31 . & \text { DOI: }\end{array}$ 10.3846/16484142.2015.1063084.

Leite, D.M., Fernandes, H.C., Teixeira, M.M., Cecon, P.R., Furtado Júnior, M.R., 2017. Dynamic traction of a mechanized set based on technical and operational parameters. Engenharia Agrícola, 37(3), 484-492. DOI: 10.1590/1809-4430eng.agric.v37n3p484-492/2017.

Mamkagh, A.M., 2018. Effect of tillage speed, depth, ballast weight and tire inflation pressure on the fuel comsuption of the agricultural tractor: a review. Journal of Engineering Research and Reports, 3(2), 1-7. DOI: 10.9734/jerr/2018/v3i216871.

Mialhe, L.G., 1974. Manual de mecanização agrícola. São Paulo, Agronômica Ceres.

Mialhe, L.G., 1996. Máquinas agrícolas - ensaios e certificação. Piracicaba, FEALQ.

Mion, R.L., Holanda, A.S., Barroso, S.H.A., Silva, S.A.T., 2016. Tensões aplicadas no solo pelas diferentes pressões do pneu de um trator agrícola. Engenharia Agrícola, 36(1), 63-77. DOI: 10.1590/1809-4430-Eng.Agric.v36n1p63-77/2016.

Misiewicz, P.A., Blackburn, K., Richards, T.E., Brighton, J.L., Godwin, R.J., 2015. The evaluation and calibration of pressure mapping system for the measurements of the pressure distribution of agricultural tyres. Biosystems Engineering, 130, 81-91. DOI: 10.1016/j.biosystemseng.2014.12.006.

Montanha, G.K., Guerra, S.P.S., Sanchez, P.A., Campos, F.H., Lanças, K.P., 2011. Consumo de combustível de um trator agrícola no preparo do solo para a cultura do algodão irrigado em função da pressão de inflação nos pneus. Energia na Agricultura, 26(1), 39-51. 10.17224/EnergAgric.2011v26n1p39-51.

Rosca, R., Cârlescu, P., Tenu, I., 2014. A semi-empirical traction prediction model for an agricultural tyre, based on the super ellipse shape of the contact surface. Soil e Tillage Research, 141, 10-18. DOI: 10.1016/j.still.2014.03.007. 
Santos, D.W.F.N., Forastiere, P.R., Furtado Júnior, M.R., Valente, D.S.M., Fernandes, H.C., 2016. Parâmetros ergonômicos e operacionais de um conjunto trator-escarificador em função da rotação do motor e pressão interna dos pneus. Revista de Ciências Agrárias, 59(4), 401-408. DOI: 10.4322/rca.2574.

Sichocki, D., Ruas, R.A.A., Dezordi, L.R., Caixeta, L.F., Silva, B.M., 2013. Consumo energético e patinagem de um trator agrícola tracionando uma enxada rotativa e um arado de discos. Revista Engenharia na Agricultura - REVENG, 21(5), 441-446.

Simões, D., Silva, M.R.D., Fenner, P.T., 2011. Desempenho operacional e custos da operação de subsolagem em área de implantação de eucalipto. Bioscience Journal, 27(5), 692-700.
Spagnolo, R.T., Volpato, C.E.S., Barbosa, J.A., Palma, M.A.Z., Barros, M.M., 2012. Fuel consumption of a tractor in function of wear, of ballasting and tire inflation pressure. Engenharia Agrícola, 32(1), 131-139. DOI: 10.1590/S010069162012000100014 .

Taghavifar, H., Mardani, A., 2014. On the modeling of energy efficiency indices of agricultural tractor driving wheels applying adaptive neuro-fuzzy inference system. Journal of Terramechanics, 56, 37-47. DOI: 10.1016/j.jterra.2014.08.002. 